\title{
Populism and Euroscepticism in the European Union
}

Matthijs Rooduijn and Stijn van Kessel $^{1}$

Version accepted for publication (May $\left.8^{\text {th }} 2019\right)$.

Final version: Rooduijn, M., \& van Kessel, S. (2019). Populism and Euroskepticism in the European Union. In Oxford Encyclopedia of European Union Politics. Oxford University Press. doi:10.1093/acrefore/9780190228637.013.1045.

\section{Summary}

This contribution provides an overview of some of the key literature on populism and Euroscepticism, with the aim to identify how the two concepts are related. It focuses on the political supply side (political parties) as well as the demand side (citizens), and argues that there is considerable affinity between populism and Euroscepticism, and that both phenomena can often be observed in tandem. In practice, many populist parties are Eurosceptic, and many Eurosceptic parties are populist. Euroscepticism and populism can typically be found at the ideological fringes of party systems, in particular among parties with radical left socioeconomic positions, on the one hand, and radical right sociocultural positions, on the other. Whilst little is known about the relationship between populist and Eurosceptic attitudes among citizens, it is clear that such attitudes contribute to support for populist and Eurosceptic parties. Irrespective of conceptual and empirical affinity, the phenomena do not always co-occur, and are inherently distinct. Notably, populism is a general set of ideas about the functioning of democracy, Euroscepticism concerns a position towards a more concrete political issue (European integration).

Keywords: Populism, Euroscepticism, political parties, European Union, European politics, radical right, radical left, voting behaviour

\footnotetext{
${ }^{1}$ The work of Van Kessel was informed by his research on the project '28+ Perspectives on Brexit: a guide to the multi-stakeholder negotiations', which is supported by the Economic and Social Research Council [grant number ES/R001847/1].
} 


\section{Introduction}

Both populism and Euroscepticism have become buzzwords among political scientists and commentators alike. The two concepts are frequently used in the context of developments in $21^{\text {st }}$ century European politics, not least the increased popularity of populist political actors, and the various crises and divisions the EU is facing. What is more, the surge of Eurosceptic populist parties in the 2014 European Parliament election, their continued success in the subsequent edition, and the UK's referendum vote to leave the EU in 2016, were examples of how the two phenomena can interact. Indeed, the 'Brexit' vote was, not least by critics of the EU, often interpreted in a typical populist fashion: as a blow to unresponsive Europhile elites (both at the national and supranational level), who sought to force through further European integration without the people's approval.

This contribution, seeks to provide an overview of some of the key literature on populism and Euroscepticism, with the aim to identify how the two concepts are related. It mainly rely on findings from existing research, in addition to some survey data. After a discussion of key definitions of both concepts, and how they relate to one another in theory, the text is divided into two main sections: one on political parties, and one on voters. They ask similar questions: what kind of voters and parties are populist and Eurosceptic, and what explains their populism and Euroscepticism? Why do individuals support Eurosceptic and populist parties; and what are the consequences of their rise? Last but not least: do we always see populism and Euroscepticism in tandem? The final section concludes and identifies areas for further research. 


\section{Definitions of Populism and Euroscepticism}

In 2019, the academic literature on populism celebrates its fiftieth anniversary. In 1969, a conference at the London School of Economics resulted in a volume edited by Ghita Ionescu and Ernest Gellner (1969), in which scholars from various academic backgrounds addressed the topic. One of the main conclusions: it was impossible to come up with a definition of populism on which everybody agreed. About a decade later, Margaret Canovan (1981) reached a similar conclusion. After the turn of the millennium, however, a change could be observed (see Taggart 2000). Although disagreement prevailed, many scholars at this point conceived of populism as a set of ideas, according to which the 'virtuous people' are exploited, neglected or betrayed by a 'corrupt elite'. According to the widely adopted definition of Cas Mudde (2004: 543), populism can be seen as 'an ideology that considers society to be ultimately separated into two homogeneous and antagonistic groups, "the pure people" versus "the corrupt elite", and which argues that politics should be an expression of the volonté générale (general will) of the people' (Mudde 2004: 543). Although scholars disagree on whether populism should be conceived of as an ideology (Mudde 2004), discourse (Hawkins 2010), style (Moffitt 2016), frame (Aslanidis 2015) or claim (Bonikowski and Gidron 2015), many share the view that populism constitutes a message or set of ideas revolving around the normative distinction and antagonistic relationship between the 'good people' and the 'evil elite'.

Alternative approaches to populism are often inspired by the work of Ernesto Laclau (2005; see also De Cleen et al. 2018). For Laclau, populism should not be seen as a trait of individual political actors, but rather as a logic of political mobilisation centred on a dichotomy between the people (discursively constructed through a 'chain of equivalence') and (those in) power. In other words, populism's meaning can be found 'in a particular mode of articulation of whatever social, 
political or ideological contents' (Laclau 2005: 34). Laclau, in fact, goes as far as to argue that populism is the central logic to all political agency. If taken this far, the approach can be criticised for reducing the concept's usefulness for empirical application, in particular if the aim is discriminating between political actors and types of behaviour. For the purpose of this contribution, it would also become difficult to point out concrete similarities and differences between the concepts of populism and Euroscepticism. Taking this into consideration, this contribution starts out from the widely adopted, and previously described, 'ideational approach' to populism (see Hawkins et al. 2018a).,

The conceptual debate on Euroscepticism is more recent. This is not surprising, given that the public salience of European integration has increased only towards the end of the $20^{\text {th }}$ century - in particular since the Maastricht Treaty in 1992, whose ratification changed the EU in a multi-level polity with greater levels of sovereignty pooled at the supranational level (see Hooghe and Marks 2009). Paul Taggart introduced one of the earliest definitions of Euroscepticism. Accordingly, 'Euroscepticism expresses the idea of contingent or qualified opposition, as well as incorporating outright and unqualified opposition to the process of European integration' (Taggart 1998: 366). Later studies have built on this conceptualisation, and distinguished between different types and degrees of opposition to European integration and the EU. Szczerbiak and Taggart (2000; see also Taggart and Szczerbiak 2004) broke down the concept into 'hard' and 'soft' Euroscepticism. The 'hard' variant refers to outright rejection of the idea of European integration and opposition to EU membership. The 'soft' alternative implies contingent or qualified opposition to integration. Kopecký and Mudde (2002) criticised this distinction on various grounds, and proposed an alternative two-dimensional conceptualisation by distinguishing 'diffuse' from 'specific' support for European integration. 'Diffuse' support 
refers to support for the general ideas of European integration, and 'specific' support to endorsement of the general practice of integration. Accordingly, they identified two types of 'EU-pessimist' parties: 'Eurosceptics' and 'Eurorejects'. Whereas 'Eurosceptics support the general ideas of European integration, but are pessimistic about the EU's current and/or future reflection of these ideas', Eurorejects 'subscribe neither to the ideas underlying the process of European integration nor to the EU' (Kopecký and Mudde 2002: 302). Later studies of Euroscepticism have built on these articles and have formulated slightly different typologies (see Flood and Usherwood 2005; Szczerbiak and Taggart 2008).

When one compares definitions of populism and Euroscepticism, several differences can be distinguished, but also scope for correspondence between the two concepts. Let us start with the differences. In comparison with Euroscepticism, the ideas central to populism are more abstract: they do not refer to specific policy areas or political institutions, but rather to the relationship between two very general constructs: 'the people' and 'the elite'. The specific interpretation of these two constructs varies depending on context and the specific incarnation of populism. Populism has been described as a 'thin' ideology that can be combined with a variety of 'host ideologies' (e.g. Mudde 2004). Radical right-wing populists, for instance, typically construct 'the people' with reference to their ethnicity or cultural background, and criticise culturally liberal elites who promote the decay of traditional norms, and fail to protect the people from adverse societal change - not least in the form of immigration. Left-wing populists instead focus primarily on socio-economic issues, and interpret the two key constructs to populism accordingly. They thus oppose privileged elites and agents of neo-liberalism, who act against the interest of the economically downtrodden people. 
Euroscepticism, by contrast, denotes something more concrete: opposition to European integration and/or the current functioning of the EU. In other words, whereas populism concerns a more abstract moral interpretation of the political world, Euroscepticism involves attitudes and positions on a concrete issue (European integration). That said, the EU can still be criticised from a wide variety of (ideological) perspectives. Eurosceptics favouring economic freedom and open borders may balk at the construction of a 'social Europe' characterised by redistributive mechanisms. Left-wing critics, on the other hand, may consider the EU as a neo-liberal project, primarily pandering to business interests.

The existence of a wide variety of possible 'Euroscepticisms' also implies that that populism and Euroscepticism do not always coexist. Criticism of European integration is not always framed in a populist manner, i.e. by referring to the antagonism between 'people' and 'elites'. At the same time, populists in Europe may not be particularly concerned with the issue of European integration, and in some instances even see it as a means to limit the power and counter the adverse policies of domestic elites (Pirro and Van Kessel 2017).

Yet, in practice, populism and Euroscepticism can often be found in a symbiotic relationship. Populists have many reasons to oppose the EU. First, they are prone to dislike the ostensibly complex and opaque European decision-making processes, which stand in the way of the direct implementation of the popular will. The EU can also easily be interpreted as an elitedriven organisation, that stands far removed from ordinary citizens. Observing the populist love for transparency and hatred of backroom deals, shady compromises and complicated technicalities, Canovan (1999: 6) argued that European Union politics resembles a 'sitting duck' for populist attacks (see also Leconte 2015). Populist Euroscepticism can be directed both at national political elites supportive of European integration, as well as EU officials in 'Brussels'. 
As discussed in the next section, left-wing and right-wing populist incarnations in Europe are also driven to Euroscepticism because of their more specific ideological characteristics.

\section{Political Parties}

\section{Euroscepticism}

At the political 'supply side', Euroscepticism is typically associated with, and expressed by, political parties. Early studies of Euroscepticism tended to classify parties as either Eurosceptic/EU-pessimist or not (see Kopecký and Mudde 2002; Taggart 1998; Taggart and Szczerbiak 2004). Paul Taggart (1998) observed that Euroscepticism was occasionally found in (factions of) traditional establishment parties, but that it is a more typical feature of parties on the periphery of their respective party systems. In more recent work, Taggart and Szczerbiak (2013) observed that mainstream parties have increasingly adopted Eurosceptical positions as well, and that Eurosceptic parties that previously operated at the fringes have been 'coming in from the cold' in terms of electoral strength and influence. Given these developments, it makes sense to conceive of Euroscepticism as a matter of degree rather than kind. Accordingly, various studies have made use of more fine-grained measures of party positions on European unification. Ray (1999), for instance, asked country experts about parties' positions on European integration, how important these parties considered the issue, and the degree of internal disagreement over the issue. Later studies have built on this work - most notably the Chapel Hill Expert Survey. ${ }^{2}$

What explains Euroscepticism among parties? Some have argued that Euroscepticism is mainly a result of strategic positioning (Sitter 2001). Taggart (1998), for instance, argued that

\footnotetext{
${ }^{2}$ Note that Cas Mudde (2011) extensively discusses two schools of Euroscepticism studies: Sussex and North Carolina. The 'Sussex school' mostly employs the party family approach and the 'North Carolina school' the matter of degrees approach.
} 
European integration tends to be a secondary issue for peripheral parties; their Euroscepticm is, first of all, a means to demonstrate their distance from the, generally pro-European, political establishment. Others have claimed that party ideologies and historical cleavages play a key role (Marks and Wilson 2000). Hooghe et al. (2002) showed that one of the strongest correlates of parties' Euroscepticism is their left-right position. More specifically, they showed that a scatterplot of left-right position on the horizontal axis and support for European integration on the vertical axis takes the shape of an '(inverted) U-curve': both radical left and right parties are more likely to be Eurosceptic. Other studies have confirmed this inverted U-curve (Aspinwall 2002; De Vries and Edwards 2009). Halikiopoulou et al. (2012) argued that the reason for this shared Euroscepticism at the fringes of the political spectrum is a shared nationalist ideology. Yet, although studies have convincingly shown that parties at the ideological fringes tend to share Eurosceptic positions, it is important to emphasise that the radical left and right express distinctive arguments against the EU (Conti and Memoli 2012), and use different 'frames' in opposing European integration (Helbling et al. 2010; Pirro et al. 2018). The radical right typically portrays the EU as a project that threatens the sovereignty of the native people and, through the opening of borders, the cultural homogeneity of nations. Radical left parties typically describe European integration as a neo-liberal project that encourages a 'race to the bottom' in terms of welfare entitlements and working conditions. It is also worth highlighting that the inverted U-curve is not necessarily time-independent. Radical right parties like the Front National have developed from being relatively positive about the EU to being distinctly negative about European integration (Mudde 2007).

We know only relatively little about the consequences of the rise of Eurosceptic parties (Vasilopoulou 2013). Meijers (2017) demonstrated that the success of Eurosceptic parties can 
fuel Euroscepticism among mainstream parties - under the condition that the Eurosceptic challengers consider the EU issue to be important. Meijers found that mainstream left parties are more strongly affected by Eurosceptic challengers, because they feel threatened by the success of both radical left and right challengers. Mainstream right parties, conversely, are only susceptible to radical right successes. On the basis of another study on party competition, Szöcsik and Polyakova (2018) suggested that far right parties may benefit electorally when centre-right parties incrementally move towards - and thus legitimise - their Eurosceptic positions. When the centre-right co-opts the far right's position on European integration fully, however, the latter is likely to suffer. As far as public contestation over European integration is concerned, several scholars have argued that Eurosceptic parties - populist radical right ones in particular - are the most likely political actors to mobilise Eurosceptic sentiments and increase the salience of EUrelated issues (e.g. Hoeglinger 2016; Kriesi 2016; Grande and Hutter 2016).

\section{Populism}

Similar to Euroscepticism, populism in the European context is typically associated with political parties - including parties, such as the Italian Five Star Movement (M5S) and the Spanish Podemos, which like to present themselves as 'movements' to emphasise their presumed closeness to 'the people'. Several studies identify political parties that can be classified as 'populist parties' due to the prominence and consistency of populism in their discourses (Rooduijn 2018; Van Kessel 2015). There are many borderline cases of populism, however. Parties can express populism to a lesser or greater extent, and, given that populism is ostensibly easier to adopt and discard than more concrete policy positions, may not stay populist over time. Several studies thus take a 'degreeist' approach, and measure levels of populism among populist 
parties and politicians by means of content analyses (Deegan-Krause and Haughton 2009; Hawkins 2009; Jagers and Walgrave 2007; Manucci and Weber 2017; Pauwels 2011; Rooduijn et al. 2014), expert surveys (Polk et al. 2017; Wiesehomeier 2018), or surveys among politicians (Andreadis and Ruth 2018; Stavrakakis et al. 2017). Several of these studies have shown that the degree of populism among parties can be measured validly and reliably (see Rooduijn and Pauwels 2011), and confirm that there are quite a few borderline cases: parties that express populist messages to some extent, but do not emphasise it strongly.

Hitherto we know only relatively little about the factors that fuel (or reduce) the degree of populism among parties. In line with the inverted U-curve previously discussed, Rooduijn and Akkerman (2017) have found that - at least in Western Europe - it is mainly a party's left-right radicalism that determines how populist it is. In other words: both radical left and radical right parties are more likely to employ populism. A party's size, whether it is in government or opposition, and whether it has suffered electoral losses do not matter much if one controls for their radicalism. Assessing not populism, but anti-elite salience, Polk et al. (2017) came to a similar conclusion: they found that radical left and TAN (Traditional-Authoritarian-Nationalist) parties, in particular, criticise the elites. It is important to emphasise that this relationship between populism and radicalism might not exist in other parts of the world and, indeed, Europe itself. As a result of the different historical trajectories of party systems in Central and Eastern Europe, for instance, many populist parties here are not defined by radical right or left ideologies (Van Kessel 2015; Hanley and Sikk 2016).

What then explains the success of these parties? Many developments have probably played an important role: globalisation and its perceived effects (Kriesi et al. 2008), changed media landscapes (Mazzoleni et al. 2003), and levels of corruption (Hawkins et al. 2018b) are 
among the more general explanatory conditions. The edited volume of Kriesi and Pappas (2015) specifically addresses European populism 'in the shadow of the Great Recession' and concludes that, with some exceptions, economic and political crises are conducive to the growth of populism. When it comes to explaining cross-national variance, Van Kessel $(2013 ; 2015)$ has demonstrated that populist parties are most successful when established parties are widely considered unresponsive or corrupt, and populist challengers reap the rewards by presenting themselves as credible alternatives. When it comes to the voting bases of populist parties, studies indicate that electorates of different types of populist parties have only very little in common most likely because the host ideologies of the various left- and right-wing populists differ fundamentally from each other (Rooduijn 2018). The only attributes that populist voter bases seem to share is that they score low on the personality trait of 'agreeableness' (Bakker et al. 2016) and that they hold strong populist attitudes (Van Hauwaert and Van Kessel 2018).

The impact of populist parties is a topic of many studies. Communication scientists have assessed to what extent populist messages affect public opinion. Hameleers and Schmuck (2017), for instance, have demonstrated that those who support populists are affected by the messages that are regularly expressed by these parties (see also e.g. Hameleers et al. 2018). Moreover, media debates have become slightly more populist as a result of the success of populist parties (Rooduijn 2014). When it comes to mainstream parties, the impact in terms of increased populist discourse seems to be limited. Both Manucci and Weber (2017) and Rooduijn et al. (2014) have found that mainstream parties have not become more populist as a result of the increasing electoral successes of their populist challengers. Various studies have also assessed how sustainable populist parties are in government (Albertazzi and McDonnell 2015), and what their impact is on liberal democracy (Mudde and Rovira Kaltwasser 2012; Müller 2016; Pappas 
2019). The latter question remains a bone of contention in particular, although this is partly due to conceptual disagreement.

\section{Populism and Euroscepticism}

As became clear from the previous discussion, the literatures on populism and Euroscepticism among political parties are, to a certain extent, distinct in their research foci. It also appears that populism is typically treated either as a defining ideological feature of political parties, or as part of a party's discursive/strategic repertoire. Euroscepticism is more often considered as indicative of a party's stance on a specific issue: European integration. This distinction is in line with our conceptual discussion in the previous section. At the same time, however, there is conceptual affinity between populism and Euroscepticism, and both phenomena can often be observed in tandem. In practice, many populist parties are Eurosceptic, and many Eurosceptic parties are populist. Euroscepticism and populism can typically be found at the ideological fringes of party systems, in particular among parties with radical left socioeconomic positions, on the one hand, and radical right sociocultural positions, on the other. Both the populism and Euroscepticism of these parties are, moreover, informed by their 'host ideologies'. Left-wing populists dislike the EU (and the national elites) for their defence of neo-liberalism at the expense of ordinary citizens; right-wing populists dislike the EU (and national elites) for their role in undermining national sovereignty and culture.

One can further demonstrate the affinity between populism and Euroscepticism by means of expert survey data on political party positions. The first panel of Figure 1 below shows the correlation between parties' positions towards 'Europe' and the salience of their antiestablishment and anti-elite rhetoric. The second panel shows the correlation between their EU- 
position and the extent to which they believe that 'the people' or elected representatives should make the most important political decisions. Data come from the Chapel Hill Expert Survey 2017 (Polk et al. 2017). Both panels show that there is a strong correlation between the two variables $(r=-0.72$ regarding anti-elite salience and $r=-0.53$ concerning the choice between 'the people' versus elected representatives). Although neither of these variables fully capture the concept of populism - given that they measure two of its constitutive attributes separately - they suggest that there is a strong correlation between populism and Euroscepticism in practice.

Figure 1: Euroscepticism (1 = strongly in favour of European integration; 7 = strongly opposed $)$ and anti-elite salience $(0=$ not important at all; $10=$ extremely important $)$ (left panel) and 'the people' versus elected representatives $(0=$ not important at all; $10=$ extremely important) (right panel) among parties (CHES 2017)

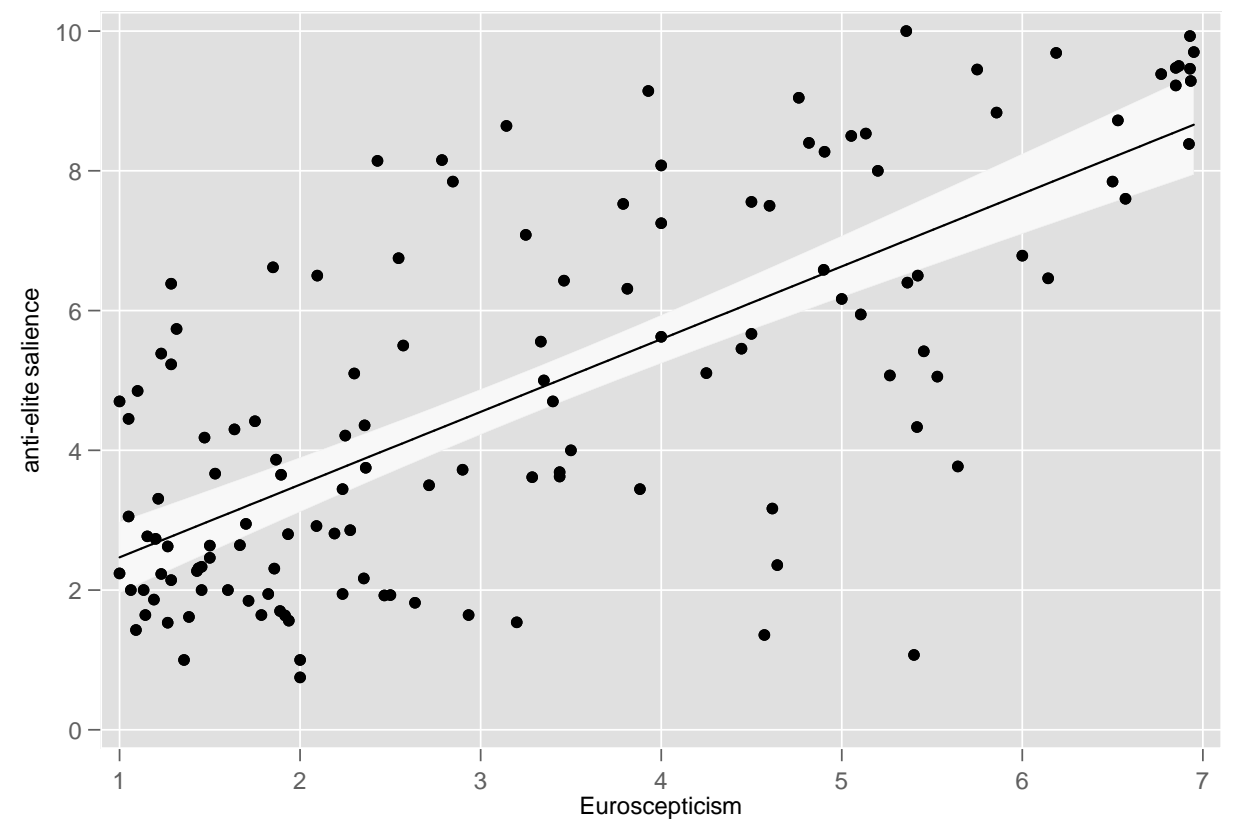




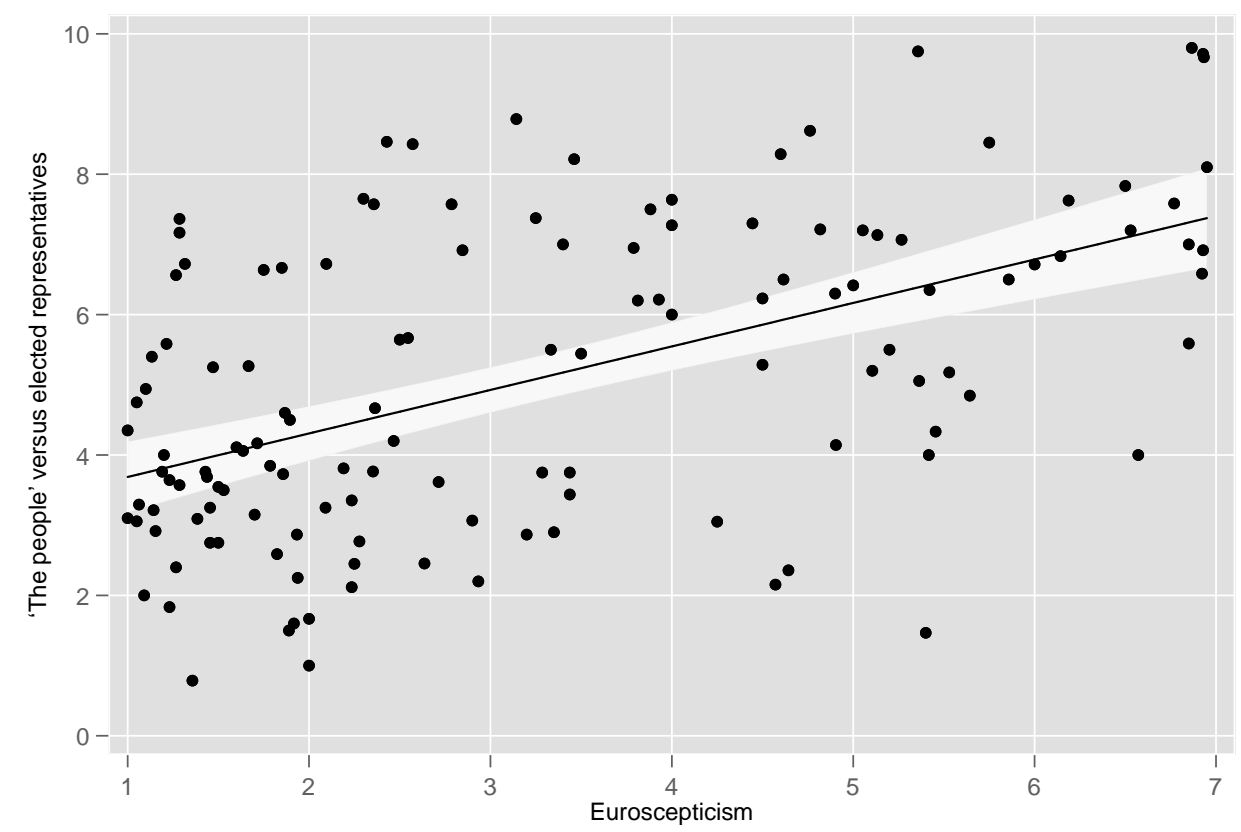

The figure also suggests, however, that populism and Euroscepticism do not always go hand in hand. Examples of populist parties that are not Eurosceptic are Silvio Berlusconi's Forza Italia, and various 'reform parties' in Central and Eastern Europe (e.g., Citizens for European Development of Bulgaria (GERB) in Bulgaria, Alliance of the New Citizen (ANO) in Slovakia, and Zatler's Reform Party (ZRP) in Latvia). At the same time, there are also examples of Eurosceptic parties that are not populist: the Conservatives in the UK, and many of the far left parties in Scandinavia and Western Europe. ${ }^{3}$ This composite picture is also illustrated by the make-up of political groups in the European Parliament: populist parties - even those with similar ideological profiles - are spread out across several groups, in some of which they collaborate with mainstream parties (see McDonnell and Werner 2018a).

It is also important to emphasise that populist parties are not similar in the degree of their Euroscepticism. Studying radical right parties (which can typically be considered populist as

\footnotetext{
${ }^{3}$ Although far left parties are clearly more populist than mainstream parties (Rooduijn and Akkerman 2017), we do not think that they should all be classified as being fully populist.
} 
well), Sofia Vasilopoulou $(2011 ; 2018)$ identified three patterns of opposition to European integration ('rejecting', 'conditional' and 'compromising'), thus outlining different degrees and types of opposition among these parties. A collection of articles in a special issue of Politics also showed diversity among populist parties, both in terms of their opposition towards Europe, as well as the framing and the salience of the issue in their discourse (see Pirro et al. 2018).

Generally speaking, radical right-wing populists are more staunchly opposed to the EU than leftwing populists. In addition, three 'crises' faced by the EU (the Great Recession, the migrant crisis and Brexit) were met with different responses from populist parties across borders. In terms of salience, European integration ultimately appears a secondary issue for most populist parties.

Given these observations, party scholars should beware of conflating populism and Euroscepticism, or to assume that the two always go together. ${ }^{4}$ At the same time, the affinity between the two concepts should encourage them to look beyond the borders of their own research area, in search for interesting new research questions and hypotheses.

\section{Voters}

\section{Euroscepticism}

Euroscepticism is not a prerogative of political parties (or the more general 'supply side' of politics); it can also be found among voters on the 'demand side' (De Vries 2018). Early studies of Euroscepticism as an attitude among citizens measure it as a single dimension assessing opposition against (or support of) European integration (see Hooghe and Marks 2005). Others

\footnotetext{
${ }^{4}$ It is important to emphasise that for most parties populism and Euroscepticism are of secondary importance (see Taggart 2000; Mudde 2004). Populist radical right parties, for instance, are first and foremost nativist; populist radical left parties favour economic redistribution above all. Although populism plays an important role in the manner in which their worldview and analyses are framed, it is not the main ideological ingredient.
} 
have argued, however, that Euroscepticism consists of various dimensions (see Lubbers and Scheepers 2010). Boomgaarden et al. (2011), for instance, argued that there are five dimensions of EU attitudes: performance, identity, affection, utilitarianism and strengthening. Van Elsas (2017) made a distinction between two dimensions of Euroscepticism: opposition to EU strengthening (i.e. defending the nation state against 'more Europe') and dissatisfaction with the current EU (i.e. negative evaluations of how the EU actually functions). Hobolt and De Vries (2016) distinguished 'regime support' (denoting support for the constitutional settlements of the EU) and 'policy support' (relating to the content of collective decisions and actions of EU actors). On the basis of these two dimensions, De Vries (2018) later developed (and empirically confirmed) a four-fold typology, including 'loyal support' and 'exit scepticism' as the two extremes, and 'policy scepticism' and 'regime scepticism' as two variants of more ambivalent scepticism.

Various studies of Euroscepticism as an attitude have assessed to what extent the inverted U-curve (i.e. the correlation between Euroscepticism and left/right radicalism) that was found at the party level is also visible at the citizen level. These studies came to diverging conclusions. Some have found that those with left-wing attitudes are more likely to be Eurosceptic (Alvarez 2002); some that right-wing citizens are more negative about the EU and European integration (McLaren 2007); and others that the correlation between left/right position and Euroscepticism is very weak (Gabel 2000). Van Elsas et al. (2016) have shown that Euroscepticism among those on the left is related to both economic and cultural attitudes, as well as concerns about how the EU currently functions. Their negative attitudes towards the EU are not, however, grounded in opposition to European integration as such. Right-wing Eurosceptics, on the other hand, object to the EU on cultural grounds, and principally reject European unification. Garry and Tilley (2015) 
have found that it is also important to take into account the economic context: economically leftwing citizens who live in a country with high income inequality are positive about European integration, whereas citizens with left-wing attitudes who live in a country where inequality is low are more negative about the EU. De Vries (2018) also emphasised the role of geographical context and socioeconomic conditions in mapping different forms of EU-support and scepticism.

Studies assessing the roots of Euroscepticism have generally focused on three general approaches: the utilitarian, identity and cue-taking approach (Hobolt and De Vries 2016; see also Eichenberg and Dalton 1993). According to the utilitarian approach, those who fare better socioeconomically will be more positive about European integration because they profit from European trade liberalisation and the opening of borders. Many studies have indeed found that this is the case (see Gabel and Palmer 1995). Some have emphasised, however, that this effect is conditional on national contextual factors (Brinegar and Jolly 2005). Another study showed that the negative effect of education on Euroscepticism has increased over the years, in particular since the signing of the Maastricht treaty (Hakhverdian et al. 2013). Further, it has been shown that, when assessing the effects of socioeconomic positions on attitudes about the EU, it is important to make a distinction between attitudes towards 'deepening' and 'broadening' of European integration (Hobolt 2014). According to the identity approach, the EU is about more than just trade liberalisation and economic calculus. Feelings of (national) identity and perceived threats play a major role when it comes to explaining Euroscepticism (Carey 2002; McLaren 2002). The core message of the cue-taking and benchmarking approaches is that citizens use information shortcuts when they form their opinions (see Lupia 1994). For instance, the EUmessages expressed by political parties (Steenbergen et al. 2007) and the way in which media 
cover the EU issue (De Vreese and Boomgaarden 2003, 2006) play an important role regarding EU attitude formation (also see Gabel and Scheve 2007).

Several studies also show that an individual's personality is related to their attitudes about Europe. Focusing on Danish and Swedish data, Nielsen (2016) found that 'extraversion' and 'openness' have a positive effect on EU attitudes, whereas those who score high on 'neuroticism' are more negative about the EU - yet none of these effects was consistently statistically significant. Based on a survey conducted in the UK, Curtis (2016) found that openness to experience and extraversion increase identification with Europe, whereas agreeableness decreases it. Investigating the Dutch case, Bakker and De Vreese (2016) discovered that the effects of personality traits depend on whether one looks at attitudes vis-à-vis widening or deepening of European integration, as well as trust, identity or affect towards the EU. Curtis and Nielsen (forthcoming) demonstrated that the effect of personality on EU support is mediated by ideological self-placement.

Do Eurosceptic attitudes also translate into support for Eurosceptic parties? Studies of voting behaviour have indicated that Eurosceptic attitudes matter. Those with more negative ideas about the EU are more likely to vote for Eurosceptic parties (De Vries 2018; Hernández and Kriesi 2016; Treib 2014; Van Spanje and De Vreese 2011). These attitudes are likely fuelled by the media debate. It has been shown that citizens who are exposed to negative evaluations of the EU are more likely to vote for a Eurosceptic party (Van Spanje and De Vreese 2014). Socioeconomic positions and crises impacting on these positions play an important role too. Citizens who experienced negative economic consequences of the financial crisis and who disapproved of the EU's handling of the crisis were more likely to vote for Eurosceptic parties (Hobolt and De Vries 2016). 
Other studies have similarly shown that Euroscepticism has a positive effect on voting for populist parties (Van Bohemen et al. 2018), voting for radical right parties (Werts et al. 2013), radical left parties (Beaudonnet and Gomez 2017), and challenger parties (De Vries and Hobolt 2012). A study of McDonnell and Werner (2018b), however, suggested that attitudes towards European integration are not a strong determinant of radical right populist support. Their findings indicate that radical right parties and their supporters are not necessarily closely aligned on the issue of European integration, and that immigration is a much more important mobilising theme (see also Hoeglinger 2016). De Vries (2007) previously showed that the degree to which EUattitudes have an effect on national vote choices is conditional upon how salient the EU is among voters and how strong the partisan conflict over Europe is.

As far as studies with a slightly different focus are concerned, Hobolt et al. (2009) demonstrated that Euroscepticism increases the likelihood of defection from a government party during EP elections. Defection rates are particularly high when the media coverage of the EU is more hostile. It has also been demonstrated that EU attitudes affect the vote choice during referendums related to European integration (Hobolt 2009). Only very few studies have assessed the impact of Euroscepticism on public policy (for an exception see Bølstad 2015).

\section{Populism}

Research on populism as an attitude among citizens is relatively new. Hawkins et al. (2012) and Akkerman et al. (2014) were among the first to demonstrate that populism can also be measured at the mass level. They measured populism by means of a scale consisting of various items like 'I would rather be represented by a citizen than by a specialized politician' and 'The politicians in parliament need to follow the will of the people'. Later studies have focused more in-depth on 
questions relating to validity. This concerns questions such as whether the scale measures one or various underlying dimensions (Schulz et al. 2017; Van Hauwaert et al. 2018); to what extent these attitudes can be distinguished from other measures of discontent (Spruyt et al. 2016); and to what extent these measures can be applied across cases and over time (Castanho Silva et al. 2018).

We know only relatively little about the roots of such populist attitudes. Focusing on the Belgian context, Elchardus and Spruyt (2016) have found that populism as an attitude is mainly a consequence of 'declinism' (i.e. the feeling that one's society is in decline, and that one is unable to live up to the new challenges), and 'relative deprivation' (i.e. the feeling of belonging to a group of people that is treated unfairly). This raises the question of to what extent someone's personality affects their degree of populism. A study by Fatke (2018) focused on the Big Five personality traits and found that the effect of personality traits on populism differs between countries: there is no single trait that consistently predicts someone's degree of populism across cases. A study of populist attitudes in Switzerland (Bernhard and Hänggli forthcoming) found that in this country populist attitudes are strongest among right-wing citizens. They argued that this is likely due to context factors (absence of a long-lasting economic crisis, widespread identity politics, and widespread mobilization by radical right parties).

Interestingly, we know more about the consequences of having a populist attitude. Akkerman et al. (2014) have demonstrated that, in the Netherlands, those with populist attitudes are more likely to vote for populist parties on the radical left (Socialist Party) and right (Party for Freedom). Assessing survey data from nine countries, Van Hauwaert and Van Kessel (2018) confirmed this relationship between populist attitudes and populist party support. Populist attitudes are shown to be unique and distinct from more basic sentiments of protest or 
dissatisfaction, which suggests that populist party supporters - who are still often portrayed as uninformed protest voters - actually have specific ideas about the functioning of democracy that are important to understand their political behaviour. Moreover, the authors showed that populist attitudes can even predict supporting a populist party whose host ideology does not match a person's own policy attitudes. Other studies have demonstrated that populist attitudes matter beyond party support. Jacobs et al. (2018) demonstrated that those with populist attitudes support referendums, and that they are more likely to cast a 'No'-vote during a referendum, no matter what their party preference is. Spierings and Zaslove (2017) suggested that populism can explain the gender gap in voting for populist parties: populist attitudes ostensibly turn women away from voting for the populist radical left and right.

\section{Populism and Euroscepticism}

When it comes to 'demand side' studies of populism and Euroscepticism, the literature on Euroscepticism is more developed in identifying various dimensions of public Euroscepticism, and tracing down its roots and interaction with other policy positions. That said, studies in both fields have shown that populist and Eurosceptic attitudes matter as far as political behaviour, and vote choice in particular, are concerned. There are also similarities in terms of methodology. When it comes to populism and Euroscepticism among voters, scholars make use of a 'degreeist' approach to assess how Eurosceptic or populist citizens are. In both fields, scholars have assessed questions of measurement validity as well as theoretical hypotheses about the causes and consequences of holding such attitudes.

Nevertheless, thus far we know virtually nothing about the relationship between populist and Eurosceptic attitudes. Employing the Dutch National Election Survey 2017 (NKO 2017) we 
provide a first exploration of this relationship. Our analysis demonstrates that there is a strong relationship between the two variables $(r=-.44, p<0.001)$. This is in line with our discussion of Euroscepticism on the 'supply side' of politics: there is a strong correlation between the two phenomena, but populism and Euroscepticism do by no means represent the same underlying concept.

\section{Conclusion}

Populism and Euroscepticism can easily be seen as two sides of the same coin. Both typically denote feelings of resentment against remote and unresponsive elites, and dislike of undemocratic, complex and untransparent decision-making procedures. It is no surprise, therefore, that the two phenomena tend to co-occur, both among political parties on the political 'supply side', as well as voters on the 'demand side'. Our contribution has, however, also highlighted important differences between the two concepts. Populism is a general set of ideas about the functioning of democracy, whereby the 'virtuous people' are presented in an antagonistic relationship with the 'corrupt elites'. Euroscepticism concerns a position towards a more concrete polity (the European Union) or issue (European integration).

That said, both populism and Euroscepticism can be informed by a range of 'host ideologies'. In practice, we see that Euroscepticism and populism are strong among parties and voters close to the socioeconomic left and sociocultural right extremes of the ideological spectrum. Both the populism and Euroscepticism of these political actors and individuals is informed by their more general ideologies. From the right, the EU (and national) elites are typically criticised for promoting the decay of national sovereignty and culture; from the left, they are seen as henchmen of global capitalism. At the same time, the existence of varieties of 
populism and Euroscepticism implies that the two phenomena do not always coincide; notably, not all opposition to the EU is framed in a populist manner.

Considering the separate literatures on populism and Euroscepticism, it becomes clear that there is considerable overlap. This is no surprise, given that most populist parties (and their voters) are Eurosceptic, and many Eurosceptic parties (and their voters) are populist. When both literatures are put together, they provide considerable information about the ideological positions of these parties, and the motivations of their voters. Given that the literature on populist attitudes is more recent in comparison with studies on Eurosceptic attitudes, there is still a lot more to learn about the roots of populism among individuals in particular.

At the same time, the research focus of studies on populism, on the one hand, and studies of Euroscepticism, on the other, tend to diverge. In the literature, populism is often - though by no means always - considered a key ideological or strategic trait of political actors and citizens, whereas Euroscepticism is treated more as a concrete policy position that ought to be explained with reference to ideological positions, attitudes or personality traits. Further, while the association between Euroscepticism and populism is habitually assumed and referred to, few studies genuinely investigate how the two concepts are related and how they interact in practice (see e.g. Pirro et al. 2018). Here lies further scope for research (see also Leconte 2015).

What also deserves more attention is the salience of Euroscepticism among populist parties and their supporters. It is apparent that European integration is not always a key theme for populist parties, and that their supporters may also not be motivated primarily by their position on the EU. Is the EU, unlike other more close-to-home issues such as unemployment or immigration, bound to be a secondary issue for populist parties and their supporters? Or are there certain conditions under which populist parties increase the salience of European integration, and 
make it a primary campaign theme? And are there conditions under which citizens consider the EU as a key issue that informs their (voting) behaviour?

The impact of populism and populist parties on the course of European integration is also a relevant area for further research. To what extent do Eurosceptic populist parties pull mainstream parties in a more Eurosceptic direction, in the same way that they influence them with regard to other issues (see e.g. Abou-Chadi and Krause 2018)? And what consequences do their rise ultimately have for the course of the European integration process, and the future of the European Union? Certainly in view of the UK's decision to leave the EU, demonstrating the real possibility of countries leaving instead of joining the bloc, such questions seem timelier than ever before.

\section{References}

Abou-Chadi, T. and W. Krause (2018) 'The Causal Effect of Radical Right Success on Mainstream Parties' Policy Positions: A Regression Discontinuity Approach', British Journal of Political Science, Published Online, https://doi.org/10.1017/S0007123418000029.

Akkerman, A., Mudde, C., \& Zaslove, A. (2014). How populist are the people? Measuring populist attitudes in voters. Comparative Political Studies, 47(9), 1324-1353.

Albertazzi, D., \& McDonnell, D. (2015). Populists in Power. Oxon: Routledge.

Alvarez, R. (2002). Attitudes toward the European Union: The role of social class, social stratification, and political orientation. International Journal of Sociology, 32, 58-76. 
Andreadis, I., \& Ruth, S. P. (2018). Elite Surveys. The Ideational Approach to Populism:

Concept, Theory, and Method, edited by K.A. Hawkins, R.E. Carlin, L. Littvay, and C. Rovira Kaltwasser. London: Routledge, 238-278.

Aslanidis, P. (2015). Is Populism an Ideology? A Refutation and a New Perspective. Political Studies, 64(1), 88-104.

Aspinwall, M. (2002). Preferring Europe. Ideology and national preferences on European integration. European Union Politics, 3(1), 81-111.

Bakker, B. N., \& de Vreese, C. H. (2016). Personality and European Union attitudes: relationships across European Union attitude dimensions. European Union Politics, 17(1), 25-45.

Bakker, B. N., Rooduijn, M., \& Schumacher, G. (2016). The psychological roots of populist voting: Evidence from the United States, the Netherlands and Germany. European Journal of Political Research, 55(2), 302-320.

Beaudonnet, L., \& Gomez, R. (2017). Red Europe versus no Europe? The impact of attitudes towards the EU and the economic crisis on radical-left voting. West European Politics, 40(2), 316-335.

Bernhard, L., \& Hänggli, R. (2018). Who Holds Populist Attitudes? Evidence from Switzerland. Swiss Political Science Review, 24(4), 510-524. 
Bonikowski, B., \& Gidron, N. (2015). The populist style in American politics: Presidential campaign discourse, 1952-1996. Social Forces, 94(4), 1593-1621.

Boomgaarden, H. G., Schuck, A. R., Elenbaas, M., \& De Vreese, C. H. (2011). Mapping EU attitudes: Conceptual and empirical dimensions of Euroscepticism and EU support. European Union Politics, 12(2), 241-266.

Brinegar, A. P., \& Jolly, S. K. (2005). Location, location, location: National contextual factors and public support for European integration. European Union Politics, 6(2), 155-180.

Bølstad, J. (2015). Dynamics of European integration: Public opinion in the core and periphery. European Union Politics, 16(1), 23-44.

Canovan, M. (1981). Populism. Oxford and London: Harcourt Brace Jovanovich.

Canovan, M. (1999). Trust the People! Populism and the Two Faces of Democracy. Political Studies, 47 (1), 2-16.

Carey, S. (2002). Undivided loyalties: is national identity an obstacle to European integration? European Union Politics, 3(4), 387-413. 
Castanho Silva, B., Andreadis, I., Anduiza, E., Blanuša, N., Corti, Y. M., Delfino, G., ... \& Littvay, L. (2018). Public Opinion Surveys: A New Scale. The Ideational Approach to Populism: Concept, Theory, and Analysis. London: Routledge, 150-177.

Conti, N., \& Memoli, V. (2012). The multi-faceted nature of party-based Euroscepticism. Acta Politica, 47(2), 91-112.

Curtis, K. A. (2016). Personality’s effect on European identification. European Union Politics, $17(3), 429-456$.

Curtis, K. A., \& Nielsen, J. H. (2018). Predispositions matter... but how? Ideology as a mediator of personality's effects on EU support in five countries. Political Psychology, 39(6), 1251-1270.

Deegan-Krause, K., \& Haughton, T. (2009). Toward a more useful conceptualization of populism: Types and degrees of populist appeals in the case of Slovakia. Politics \& Policy, $37(4), 821-841$.

De Cleen, B., Glynos, J. \& Mondon, A. (2018). Critical research on populism: Nine rules of engagement. Organization, 25(5), 649-661.

De Vreese, C., \& Boomgaarden, H. (2003). Valenced news frames and public support for the EU. Communications, 28(4), 361-381. 
De Vreese, C. H., \& Boomgaarden, H. G. (2006). Media effects on public opinion about the enlargement of the European Union. JCMS: Journal of Common Market Studies, 44(2), 419-436.

De Vries, C. E. (2007). Sleeping giant: Fact or fairytale? How European integration affects national elections. European Union Politics, 8(3), 363-385.

De Vries, C. E. (2018). Euroscepticism and the Future of European Integration. Oxford: Oxford University Press.

De Vries, C. E. and Edwards, E. (2009). Taking Europe to Its Extremes: Extremist Parties and Public Euroscepticism. Party Politics, 15(1), 5-28.

De Vries, C. E., \& Hobolt, S. B. (2012). When dimensions collide: The electoral success of issue entrepreneurs. European Union Politics, 13(2), 246-268.

Eichenberg, R. C., \& Dalton, R. J. (1993). Europeans and the European Community: The dynamics of public support for European integration. International Organization, 47(4), 507534.

Elchardus, M., \& Spruyt, B. (2016). Populism, persistent republicanism and declinism: An empirical analysis of populism as a thin ideology. Government and Opposition, 51(1), 111-133. 
Fatke, M. (2019). The personality of populists: How the Big Five traits relate to populist attitudes. Personality and Individual Differences, 139, 138-151.

Flood, C., \& Usherwood, S. (2005, April). Positions, Dispositions, Transitions: A model of group alignment on EU integration. In 55th Annual Conference of the Political Studies Association.

Gabel, M. (2000). European integration, voters and national politics. West European Politics, 23(4), 52-72.

Gabel, M., \& Palmer, H. D. (1995). Understanding variation in public support for European integration. European Journal of Political Research, 27(1), 3-19.

Gabel, M., \& Scheve, K. (2007). Estimating the effect of elite communications on public opinion using instrumental variables. American Journal of Political Science, 51(4), 1013-1028.

Garry, J., \& Tilley, J. (2015). Inequality, state ownership and the European Union: How economic context and economic ideology shape support for the European Union. European Union Politics, 16(1), 139-154.

Grande, E. and Hutter, S. (2016). Beyond authority transfer: explaining the politicisation of Europe. West European Politics, 39(1), 23-43. 
Halikiopoulou, D., Nanou, K., \& Vasilopoulou, S. (2012). The paradox of nationalism: The common denominator of radical right and radical left euroscepticism. European Journal of Political Research, 51(4), 504-539.

Hameleers, M., Bos, L. \& de Vreese, C. (2018). Framing blame: toward a better understanding of the effects of populist communication on populist party preferences. Journal of Elections, Public Opinion and Parties, 28(3), 380-398.

Hameleers, M., \& Schmuck, D. (2017). It's us against them: A comparative experiment on the effects of populist messages communicated via social media. Information, Communication \& Society, 20(9), 1425-1444.

Hanley, S., \& Sikk, A. (2016). Economy, corruption or floating voters? Explaining the breakthroughs of anti-establishment reform parties in eastern Europe. Party Politics, 22(4), 522533.

Hawkins, K. A. (2009). Is Chávez populist? Measuring populist discourse in comparative perspective. Comparative Political Studies, 42(8), 1040-1067.

Hawkins, K. A. (2010). Venezuela's Chavismo and Populism in Comparative Perspective. Cambridge University Press. 
Hawkins, K. A., Riding, S., \& Mudde, C. (2012). Measuring populist attitudes. Committee on Concepts and Methods.

Hawkins, K. A., Carlin, R., Littvay, L., \& Rovira Kaltwasser, C. (eds.) (2018a). The Ideational Approach to Populism. Concept, Theory, and Analysis. Oxon: Routledge.

Hawkins, K. A., Kaltwasser, C. R., \& Andreadis, I. (2018b). The activation of populist attitudes. Government and Opposition, 1-25. doi:10.1017/gov.2018.23.

Helbling, M., Hoeglinger, D., \& Wuest, B. (2010). How Political Parties Frame European Integration. European Journal of Political Research, 49(4), 495-521.

Hernández, E., \& Kriesi, H. (2016). Turning your back on the EU. The role of Eurosceptic parties in the 2014 European Parliament elections. Electoral Studies, 44, 515-524.

Hobolt, S. B. (2009). Europe in Question: Referendums on European Integration. Oxford: Oxford University Press.

Hobolt, S. B. (2014). Ever closer or ever wider? Public attitudes towards further enlargement and integration in the European Union. Journal of European Public Policy, 21(5), 664-680. 
Hobolt, S. B., Spoon, J. J., \& Tilley, J. (2009). A vote against Europe? Explaining defection at the 1999 and 2004 European Parliament elections. British Journal of Political Science, 39(1), 93115.

Hobolt, S. B., \& De Vries, C. E. (2016). Public support for European integration. Annual Review of Political Science, 19, 413-432.

Hoeglinger, D. (2016). The politicisation of European integration in domestic election campaigns. West European Politics, 39(1), 44-63.

Hooghe, L., \& Marks, G. (2005). Calculation, community and cues: Public opinion on European integration. European Union Politics, 6(4), 419-443.

Hooghe, L., \& Marks, G. (2009). A Postfunctionalist Theory of European Integration: From Permissive Consensus to Constraining Dissensus, British Journal of Political Science, 39(1): 123.

Hooghe, L., Marks, G. \& Wilson, C. (2002). Does Left/Right Structure Party Positions on European Integration? Comparative Political Studies, 35(8), 965-89.

Ionescu, G., \& Gellner, E. (eds.) (1969). Populism, its Meanings and National Characteristics, London: Weidenfeld and Nicolson. 
Jacobs, K., Akkerman, A., \& Zaslove, A. (2018). The voice of populist people? Referendum preferences, practices and populist attitudes. Acta Politica, 53(4), 517-541.

Jagers, J., \& Walgrave, S. (2007). Populism as political communication style: An empirical study of political parties' discourse in Belgium. European Journal of Political Research, 46(3), 319345.

Kopecký, P., \& Mudde, C. (2002). The Two Sides of Euroscepticism. Party Positions on European Integration in East Central Europe. European Union Politics, 3(3), 297-326.

Kriesi, H. (2016). The Politicization of European Integration. Journal of Common Market Studies, 54(S1), 32-47.

Kriesi, H., Grande, E., Lachat, R., Dolezal, M., Bornschier, S., \& Frey, T. (2008). West European Politics in the Age of Globalization. Cambridge: Cambridge University Press.

Kriesi, H., \& Pappas, T. (eds.) (2015) European Populism in the Shadow of the Great Recession. Colchester: ECPR Press.

Laclau, E. (2005). On Populist Reason, London: Verso.

Leconte, C. (2015). From pathology to mainstream phenomenon: Reviewing the Euroscepticism debate in research and theory. International Political Science Review, 36(3), 250-263. 
Lubbers, M., \& Scheepers, P. (2010). Divergent trends of euroscepticism in countries and regions of the European Union. European Journal of Political Research, 49(6), 787-817.

Lupia, A. (1994). Shortcuts versus encyclopedias: Information and voting behavior in California insurance reform elections. American Political Science Review, 88(1), 63-76.

Manucci, L., \& Weber, E. (2017). Why The Big Picture Matters: Political and Media Populism in Western Europe since the 1970s. Swiss Political Science Review, 23(4), 313-334.

Marks, G., \& Wilson, C. J. (2000). The past in the present: A cleavage theory of party response to European integration. British Journal of Political Science, 30(3), 433-459.

Mazzoleni, G., Stewart, J. \& Horsfield, B. (eds.) (2003). The Media and Neo-Populism. London: Praeger.

McDonnell, D. \& Werner, A. (2018a). Respectable radicals: why some radical right parties in the European Parliament forsake policy congruence. Journal of European Public Policy, 25:5, 747763.

McDonnell, D. \& Werner, A. (2018b). Differently Eurosceptic: radical right populist parties and their supporters. Journal of European Public Policy, DOI: 10.1080/13501763.2018.1561743. 
McLaren, L. M. (2002). Public support for the European Union: cost/benefit analysis or perceived cultural threat? Journal of Politics, 64(2), 551-566.

McLaren, L. M. (2007). Explaining mass-level Euroscepticism: Identity, interests, and institutional distrust. Acta Politica, 42(2-3), 233-251.

Meijers, M. (2017). Contagious Euroscepticism. The Impact of Eurosceptic Support on Mainstream Party Positions on European integration. Party Politics, 23(4), 413-423.

Moffitt, B. (2016). The Global Rise of Populism: Performance, Political Style, and Representation, Stanford: Stanford University Press.

Mudde, C. (2004). The Populist Zeitgeist. Government and Opposition, 39(4), 542-63.

Mudde, C. (2007). Populist Radical Right Parties in Europe. Cambridge: Cambridge University Press.

Mudde, C. (2011). Sussex v. North Carolina: The Comparative Study of Party-Based Euroscepticism. SEI Working Paper No 121 / EPERN Working Paper No 23.

Mudde, C., \& Kaltwasser, C. R. (Eds.). (2012). Populism in Europe and the Americas: Threat or corrective for democracy? Cambridge: Cambridge University Press. 
Müller, J-W. (2016). What is Populism? London: Penguin.

Nielsen, J. H. (2016). Personality and Euroscepticism: The impact of personality on attitudes towards the EU. JCMS: Journal of Common Market Studies, 54(5), 1175-1198.

Pappas, T. (2019) Populism and Liberal Democracy. A Comparative and Theoretical Analysis. Oxford: Oxford University Press.

Pauwels, T. (2011). Measuring populism: A quantitative text analysis of party literature in Belgium. Journal of Elections, Public Opinion and Parties, 21(1), 97-119.

Pirro, A., \& Van Kessel, S. (2017). United in opposition? The populist radical right's EUpessimism in times of crisis. Journal of European Integration, 39(4): 405-420.

Pirro, A., Taggart, P., and Van Kessel, S. (2018). The populist politics of Euroscepticism in times of crisis: Comparative conclusions. Politics, 38(3), 378-390.

Polk, J., Rovny, J., Bakker, R., Edwards, E., Hooghe, L., Jolly, S., ... \& Steenbergen, M. (2017). Explaining the salience of anti-elitism and reducing political corruption for political parties in Europe with the 2014 Chapel Hill Expert Survey data. Research \& Politics, 4(1), 1-9.

Ray, L. (1999). Measuring party orientations towards European integration: Results from an expert survey. European Journal of Political Research, 36(2), 283-306. 
Rooduijn, M. (2014). The mesmerising message: The diffusion of populism in public debates in Western European media. Political Studies, 62(4), 726-744.

Rooduijn, M. (2018). What unites the voter bases of populist parties? Comparing the electorates of 15 populist parties. European Political Science Review, 10(3), 351-368.

Rooduijn, M., \& Pauwels, T. (2011). Measuring populism: Comparing two methods of content analysis. West European Politics, 34(6), 1272-1283.

Rooduijn, M., De Lange, S. L., \& Van der Brug, W. (2014). A populist Zeitgeist? Programmatic contagion by populist parties in Western Europe. Party Politics, 20(4), 563-575.

Rooduijn, M., \& Akkerman, T. (2017). Flank attacks: Populism and left-right radicalism in Western Europe. Party Politics, 23(3), 193-204.

Schulz, A., Müller, P., Schemer, C., Wirz, D. S., Wettstein, M., \& Wirth, W. (2017). Measuring populist attitudes on three dimensions. International Journal of Public Opinion Research, 30(2), 316-326.

Sitter, N. (2001). The politics of opposition and European integration in Scandinavia: Is Euroscepticism a government-opposition dynamic? West European Politics, 24(4), 22-39. 
Spierings, N., \& Zaslove, A. (2017). Gender, populist attitudes, and voting: explaining the gender gap in voting for populist radical right and populist radical left parties. West European Politics, 40(4), 821-847.

Spruyt, B., Keppens, G., \& Van Droogenbroeck, F. (2016). Who supports populism and what attracts people to it? Political Research Quarterly, 69(2), 335-346.

Stavrakakis, Y., Andreadis, I., \& Katsambekis, G. (2017). A new populism index at work: identifying populist candidates and parties in the contemporary Greek context. European Politics and Society, 18(4), 446-464.

Steenbergen, M. R., Edwards, E. E., \& De Vries, C. E. (2007). Who's cueing whom? Mass-elite linkages and the future of European integration. European Union Politics, 8(1), 13-35.

Szczerbiak, A., \& Taggart, P. (2000). 'Opposing Europe: Party Systems and Opposition to the Union, the Euro and Europeanisation', SEI Working Papers 2000/36.

Szczerbiak, A., \& Taggart, P. (Eds.) (2008). Opposing Europe? The Comparative Party Politics of Euroscepticism: Volume 1: Case Studies and Country Surveys. Oxford University Press on Demand. 
Szöcsik, E. \& Polyakova, A. (2018). Euroscepticism and the electoral success of the far right: the role of the strategic interaction between center and far right. European Political Science, https://doi.org/10.1057/s41304-018-0162-y

Taggart, P. (1998). A Touchstone of Dissent: Euroscepticism in Contemporary Western European Party Systems. European Journal of Political Research, 33(3), 363-88.

Taggart, P. (2000). Populism. Buckingham and Philadelphia: Open University Press.

Taggart, P., \& Szczerbiak, A. (2004). Contemporary Euroscepticism in the party systems of the European Union candidate states of Central and Eastern Europe. European Journal of Political Research, 43(1), 1-27.

Taggart, P. \& Szczerbiak, A. (2013). Coming in from the Cold? Euroscepticism, Government Participation and Party Positions on Europe. JCMS: Journal of Common Market Studies, 51(1), $17-37$.

Treib, O. (2014). The voter says no, but nobody listens: causes and consequences of the Eurosceptic vote in the 2014 European elections. Journal of European Public Policy, 21(10), 1541-1554. 
Van Bohemen, S., De Koster, W. \& Van der Waal, J. (2018). Euroscepticism among Dutch Leftist and Rightist Populist Constituencies: How can the U-Curve be Understood? JCMS: Journal of Common Market Studies, https://doi.org/10.1111/jcms.12806.

Van Elsas, E. J. (2017). Opposing a different Europe: The nature and origins of Euroscepticism among left-wing and right-wing citizens in Western Europe. PhD-thesis, University of Amsterdam.

Van Elsas, E. J., Hakhverdian, A., \& Van der Brug, W. (2016). United against a common foe? The nature and origins of Euroscepticism among left-wing and right-wing citizens. West European Politics, 39(6), 1181-1204.

Van Hauwaert, S. Schimpf, C. \& Azevedo, F. (2018). Public opinion surveys: evaluating existing measures. The Ideational Approach to Populism: Concept, Theory, and Analysis. London: Routledge.

Van Hauwaert, S. M., \& Van Kessel, S. (2018). Beyond protest and discontent: A cross-national analysis of the effect of populist attitudes and issue positions on populist party support. European Journal of Political Research, 57(1), 68-92.

Van Kessel, S. (2013). A matter of supply and demand: The electoral performance of populist parties in three European countries. Government and Opposition, 48(2), 175-199. 
Van Kessel, S. (2015). Populist Parties in Europe: Agents of Discontent? Basingstoke: Palgrave Macmillan.

Van Spanje, J., \& de Vreese, C. (2011). So what's wrong with the EU? Motivations underlying the Eurosceptic vote in the 2009 European elections. European Union Politics, 12(3), 405-429.

Van Spanje, J., \& de Vreese, C. (2014). Europhile media and Eurosceptic voting: Effects of news media coverage on Eurosceptic voting in the 2009 European parliamentary elections. Political Communication, 31(2), 325-354.

Vasilopoulou, S. (2011). European Integration and the Radical Right: Three Patterns of Opposition. Government and Opposition, 46 (2), 223-44.

Vasilopoulou, S. (2013). Continuity and Change in the Study of Euroscepticism: Plus ça change? JCMS: Journal of Common Market Studies, 51(1), 153-168.

Vasilopoulou S. (2018). Far Right Parties and Euroscepticism: Patterns of Opposition. Colchester: ECPR Press.

Werts, H., Scheepers, P. \& Lubbers, M. (2013). Euro-Scepticism and Radical Right-Wing Voting in Europe, 2002-2008: Social Cleavages, Socio-Political Attitudes and Contextual Characteristics Determining Voting for the Radical Right. European Union Politics, 14(2), 183205. 
Wiesehomeier, N. (2018). Expert surveys. The Ideational Approach to Populism: Concept, Theory, and Analysis. London: Routledge. 